cations discussed cover interstitial, intracavitary and surface treatments, and teletherapy (that is, therapeutic irradiation with collimated gamma-rays); and in the non-medical applications, specific consideration is given to the uses of sources in instrument calibration, research and civil defence exercises. Radiation hazards can be significantly reduced by the proper use of suitable facilities, and details of appropriate equipment for the safe handling, storage and transportation of the radioactive materials are given together with emergency measures to be taken when accidents such as spilling occur. The disposal of radioactive materials is not dealt with. The Handbook concludes with several tables and graphs giving data from which a worker can calculate, to suit his particular purpose, the correct arrangement and barrier thicknesses of concrete, iron or lead for any one of the three sources.

Courtaulds' Scientific and Educational Trust Fund: Postgraduate Research Scholarships for 1955

THE Courtaulds' Scientific and Educational Trust Fund has recently announced the award of postgraduate research scholarships for 1955. Scholarships in a branch of science related to the textile, plastics and allied industries (maximum of $£ 400$ for one year only, but renewable for further periods) have been awarded to the following: J. D. Coombes, University of Nottıngham; J. H. N. Hill, The Queen's University, Belfast (renewal) ; G. Holden, University of Manchester; G. R. Kotten-Kaye, Royal College of Science, Imperial College of Science and Technology, London (renewal); F. Nyman, University of Cambridge; J. H. Oxley, University College, London (renewal); M. T. Pope, University of Oxford; P. R. Sewell, University of Birmingham (renewal); R. R. Sheldon, University of Liverpool ; and T. C. Stening, King's College, London (renewal). Postgraduate research scholarships in textile technology, tenable for two years ( $\$ 320$ the first year and $£ 360$ the second) have been awarded to the following : C. B. Chapman (third-year renewal), Miss M. M. Forrester, A. F. Greenwood (third-year renewal), D. R. Hardisty (third-year renewal), J. Hope, A. T. Peters and A. Selwood (second-year renowal). The holders of these latter scholarships have all chosen to do their research at the University of Leeds, except Mr. Hardisty, who will work at the Manchester College of Technology.

\section{Mond Nickel Fellowships for 1955}

THe Mond Nickel fellowships for 1955 have been awarded to the following for study in the fields indicated: D. H. Butler (Phosphor Bronze Co., Ltd.), production of copper and its alloys, with particular attention to foundry methods, in Europe and in America; R. W. N. Dron (Rhoanglo Mine Services, Litd.), organization of research and its relation to production in extraction metallurgy in tho United Kingdom and North America; W. F. Duncan (British Aluminium Co., Ltd.), the design, layout and operation of continuous strip mills and, in particular, metal behaviour, properties and quality, roll lubrication and cooling, and the development of automatic controls; R. H. Hannaford (British Iron and Steel Research Association), organization and practice in the ferrous foundry industry in Europe and the United States, with particular reference to layout, mechanization and the application of management techniques; R. J. Harbord (John Lysaght's Scunthorpe Steelworks, Ltd.), the development of continuous casting in the non-ferrous industry and its application to the production of steel.

\section{Institute of Metal Finishing : Officers}

OFFICERS of the Institute of Metal Finishing for the session 1955-56 are as follows: President, R. A. F. Hammond; Immediate Past President, Prof. J. W. Cuthbertson ; Vice-Presidents, Dr. S. G. Clarke, Dr. T. P. Hoar, Dr. L. B. Hunt, R. W. Nicol, H. Silman, A. Smart and A. W. Wallbank ; Honorary Treasurer, F. L. James; Honorary Secretary, Dr. S. Wernick.

\section{Announcements}

Mr. W. Strath, at present serving as a Third Secretary in H.M. Treasury, has been appointed a full-time member of the Atomic Energy Authority. Sir Rowland Smith, chairman of the Ford Motor Co., and Mr. C. F. Kearton, a director of Courtaulds, Ltd., have been appointed part-time members. This brings the membership of the Authority up to the limit of ten, other than the chairman, laid down in the Atomic Energy Authority Act, 1954. Mr. Strath will be largely concerned with the Authority's relations with industry, with overseas atomic energy organizations and with raw material procurement.

A CONFERENCE on "Cloud Physics", arranged jointly by the Physical Society and the Royal Meteorological Society and organized by Prof. P. A. Sheppard, will be held in the Department of Meteorology, Imperial College of Science and Technology, Exhibition Road, London, S.W.7, during January 4-5. A number of leading workers in this field have been invited from the United States, Australia and the Continent of Europe. Further information can be obtained from the Physical Society, 1 Lowther Gardens, Prince Consort Road, London, S.W.7, marked for the attention of Miss E. Miles.

THE Worshipful Company of Glass-Sellers of London is offering up to four scholarships in glass technology, tenable at the University of Sheffield, which in suitable circumstances will be eligible for supplementation by the Ministry of Education up to the full value of State scholarships. The scholarships will be awarded by examination, for which candidates will take papers in chemistry, physics and pure mathematics (two as primary subjects and one as a secondary subject) together with an English language paper. Entry forms (to be completed by January 16) and further information can be obtained from the Registrar, University, Sheffield 10 ; the examination will begin at the University on April 9.

Thr Nationt1 sience Foundation, Washington, D.C., has appointed the following three programme directors: Dr. Helen S. Hogg, on leave of absence from the University of Toronto and the David Dunlap Observatory, to be programme director for astronomy in the Division of Mathematical, Physical and Engineering Sciences; Dr. Vernon Bryson, until recently a geneticist at the Long Island Biological Association, Cold Spring Harbor, New York, to be programme director for genetic and developmental biology in the Division of Biological and Medical Sciences; and Prof. Rogers McVaugh, on leave of absence from the University of Michigan, where he is curator of phanerogams in the University Herbarium and professor of botany, to be programme director for systematic biology in the Division of Biological and Medical Sciences. 